\title{
A Case Report of a Peripheral Giant Cell Granuloma in a Patient on Forteo
}

\author{
Flavia Pirih $^{1 *}$, Ana Dilza Barroso1, Nikolaos Tatarakis², Kitrina Cordell ${ }^{3}$, Laurie McCauley ${ }^{4}$, \\ Paul Edwards ${ }^{5}$ \\ ${ }^{1}$ Section of Periodontics, University of California Los Angeles, Los Angeles, CA, USA \\ ${ }^{2}$ Unit of Periodontology, Eastman Dental Institute, University College of London, London, UK \\ ${ }^{3}$ Division of Oral and Maxillofacial Pathology, Department of Comprehensive Dentistry, Louisiana State \\ University School of Dentistry, New Orleans, LA, USA \\ ${ }^{4}$ University of Michigan School of Dentistry, Ann Arbor, MI, USA \\ ${ }^{5}$ Department of Oral Pathology, Oral Medicine and Radiology, Indiana University School of Dentistry, \\ Indianapolis, IN, USA \\ Email: ${ }^{*}$ fpirih@dentistry.ucla.edu, ana_dilza@yahoo.com.br, kcorde@lsuhsc.edu, mccauley@umich.edu, \\ pcedward@iu.edu
}

Received 15 April 2015; accepted 20 June 2015; published 23 June 2015

Copyright (C) 2015 by authors and Scientific Research Publishing Inc.

This work is licensed under the Creative Commons Attribution International License (CC BY).

http://creativecommons.org/licenses/by/4.0/

C) (i) Open Access

\begin{abstract}
Peripheral giant cell granuloma (PGCG) is a common reactive gingival lesion that histologically resembles the central giant cell granuloma, and is a central lesion of the jaws. Occasionally, central giant cell granuloma-like lesions may be seen in association with hyperparathyroidism. Rarely, PGCG-like lesions have been described in a background of hyperparathyroidism. We describe the case of a 91-year-old woman taking teriparatide for the treatment of osteoporosis and presented with a peripheral giant cell granuloma of the mandibular posterior area.
\end{abstract}

\section{Keywords}

Peripheral Giant Cell Granuloma, Central giant Cell Granuloma, Hyperparathyroidism, Teriparatide, Parathyroid Hormone

\section{Introduction}

Peripheral giant cell granuloma (PGCG) is a common benign reactive hyperplastic lesion of the gingiva or alveolar mucosa [1]-[3], presented as a painless well-demarcated, red-purple, sessile or pedunculated exophytic

\footnotetext{
"Corresponding author.
}

How to cite this paper: Pirih, F., Barroso, A.D., Tatarakis, N., Cordell, K., McCauley, L. and Edwards, P. (2015) A Case Report of a Peripheral Giant Cell Granuloma in a Patient on Forteo. Open Journal of Stomatology, 5, 147-151.

http://dx.doi.org/10.4236/ojst.2015.56020 
soft tissue lesion that arises from the gingiva and may be secondarily ulcerated. PGCGs rarely exceed $2 \mathrm{~cm}$ in diameter [4]-[7]. PCGCs may be associated with local irritating factors, such as tooth extraction, poor dental restorations, food impaction, ill-fitting dentures and dental calculus [8]-[10]. PGCGs can occur at any age, but most commonly are noted between the fourth and sixth decades and appear to be more common in women, with the most prevalent site being the posterior mandibular alveolar mucosa [2] [4] [11] [12]. The reported recurrence varies among different studies but is considered to be approximately 10\% [1] [2] [12] [13].

PGCG is histologically indistinguishable from its central counterpart, the central giant cell granuloma (CGCG) and the brown tumor of hyperparathyroidism [14]-[18]. Histologically, these lesions demonstrate abundant multinucleated giant cells in a fibroblastic matrix [2] [4] [19]. Even though brown tumor, PGCG and CGCG are clinically and histologically similar, lesions from hyperparathyroidism are rarely observed because hyperparathyroidism is typically diagnosed at an early stage. Moreover, brown tumors of hyperparathyroidism are usually central lesions, and characterized by extensive proliferation of fibroblastic tissue and a high-number of multinucleated osteoclast-like giant cells [15]. Even though, brown tumors are usually centrally located, there have been occasional reports of PGCG-like lesions associated with hyperparathyroidism [14] [18] [20]. A key feature of hyperparathyroidism is hypercalcemia [21]. Teriparatide and recombinant PTH, utilized for the treatment of osteoporosis, can also lead to transient hypercalcemia [17] [22] [23]. If hypercalcemia was observed with teriparatide treatment, it would occur within 4 - 6 hours of teriparatide injection, returning to normal levels soon after. However, the hypercalcemia can be persistent. [22].

We describe a 91-year-old female taking teriparatide for osteoporosis and presented with presented with a recurrent peripheral cell giant granuloma of the mandibular posterior area.

\section{Case Presentation}

A 91-year-old female was referred to the University of Michigan periodontal clinic in October of 2007. The patient's medical history was significant for lymphoma initially diagnosed in 1980, knee replacement surgery in 2000, history of bisphosphonate treatment (Actonel) from 2002 to 2006, and teriparatide (Forteo ${ }^{\circledR}$ ) use from February 2006.

As part of her dental treatment, tooth \#20 was extracted in May 2007. One week after tooth extraction, thepatient presented with a purulent discharge at the extraction site, and was placed on amoxicillin. Three weeks postextraction, during a follow-up appointment, the patient reported what she believed was a root tip at the site of the extraction. On examination, a small bone sequestrum was noted, which was removed.

In October 2007, the patient was referred to the periodontal clinic for biopsy of a $1 \mathrm{~cm}$ yellow-reddish, ulcerated sessile nodulearising from the extraction socket of tooth \#20. Clinically, the lesion resembled a pyogenic granuloma (Figure 1(a)). The radiographic exam showed a normal extraction site (Figure 1(b)).

The extraction socket of tooth \#20 was curetted and an excisional biopsy was performed. Microscopically, the tissue consisted of an ulcerated section of mucosa surfaced by fibrin with enmeshed neutrophils overlying a proliferation of cellular mesenchymal tissue composed of plump, ovoid-shaped nuclei with abundant multinucleated giant cells and extravasated erythrocytes (Figure 1(c)). Foreign material was not identified. Based on the soft tissue location of the lesion, the final diagnosis was peripheral giant cell granuloma.

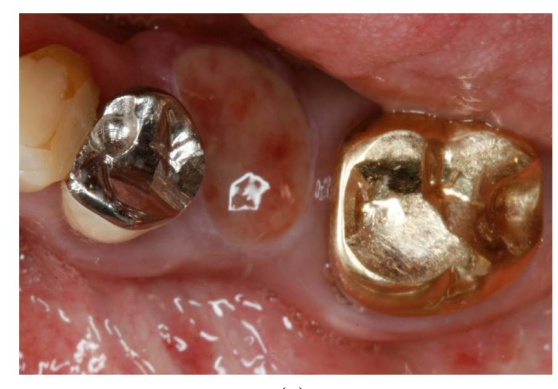

(a)

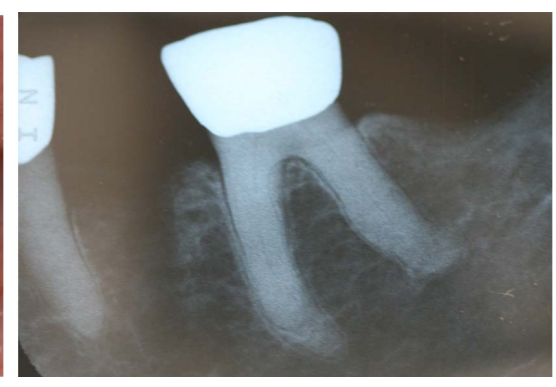

(b)

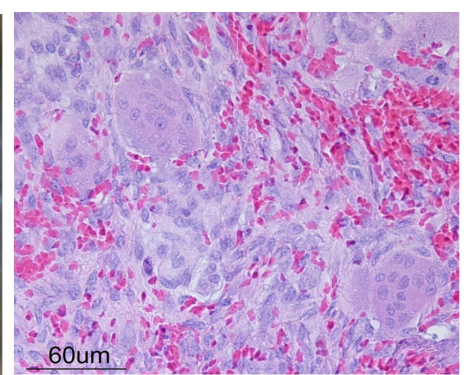

(c)

Figure 1. Mandibular lesion. (a) Intraoral view showing a yellow-reddish sessile nodular mass of about $1 \mathrm{~cm}$; (b) Periapical radiography showing no bone alterations; (c) High-power magnification of the histological specimen showing a proliferation of mesenchymal cellular tissue with abundant multinucleated giant cells, compatible with a peripheral giant cell granuloma diagnosis (hematoxylin and eosin, 40× magnification). 
At the one-week follow-up appointment, the lesion had recurred (Figure 2(a)). During that time biochemical serum analyses demonstrated elevated serum calcium and PTH levels (112 ng/L; N < 25 ng/L) [24].

One month later, re-excision was performed in the area of the recurrent lesion (Figure 2(c)), which was again consistent with a peripheral giant cell granuloma on histopathologic examination. One month post-operatively, the area had healed normally (Figure 2(d)). The patient presented for a re-evaluation appointment in January of 2008, and the area had healed uneventfully. The last follow-up with the patient was 2 months after the procedure and the lesion had not recurred by that time (Figure 2(e)).

\section{Discussion}

This case report described a 91-year-old female patient taking teriparatide for the treatment of osteoporosis and presented with a PGCG. In the case presented here, the PGCG recurred soon after the first PGCG excisional biopsy. Even though PGCGs have a history of recurrence, we hypothesized that the recurrence occurred because the patient had being treated for osteoporosis with teriparatide.

PGCC is a benign gingival lesion that may be histologically indistinguishable from CGCG. Brown tumors of hyperparathyroidism are usually located within the jaws, rendering them indistinguishable from CGCGs. However, there have been occasional reports that PGCGs can also be associated with hyperparathyroidism [14] [15] [20]. This patient was presented with elevated calcium and PTH levels which could have been associated with teriparatide use, thus the question of whether the development of the lesion was related to the use of this medication was raised. Given that hyperparathyroidism is an endocrine disorder characterized by an increase in the secretion of PTH and is associated with brown tumors [15] [21] [25] [26], our hypothesis that this lesion could have been a result of hyperparathyroidism would appear plausible. However, we cannot exclude the potential role of local irritating factors, such as the presence of small fragments of necrotic bone in the extraction site.

Our patient had elevated PTH and calcium levels. Typically, teriparatide half-life is approximately one hour when administered subcutaneously. However, there have been reports that patients with renal impairment can have an increased half-life of teriparatide. Transient hypercalcemia was observed in women treated with teriparatide and also in subjects with renal impairment [22] [27]. The cause of the elevated PTH levels and calcium levels in the patient reported here is unknown, as her glomerular filtration rate was not assessed and therefore her renal status was unknown. Moreover, a limitation of this study is that we do not have blood test results to

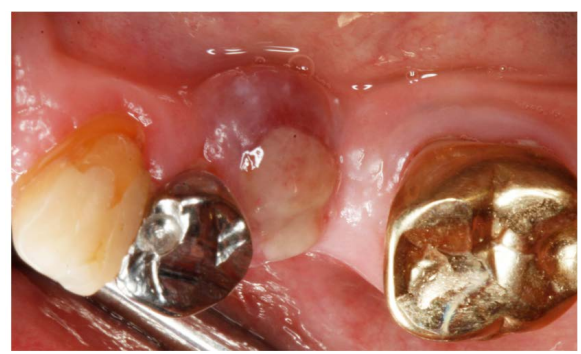

(a)

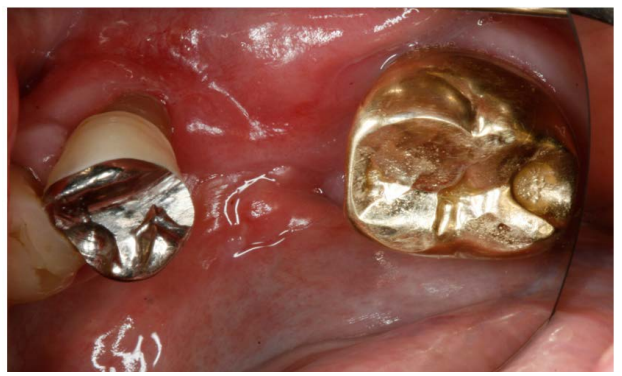

(d)

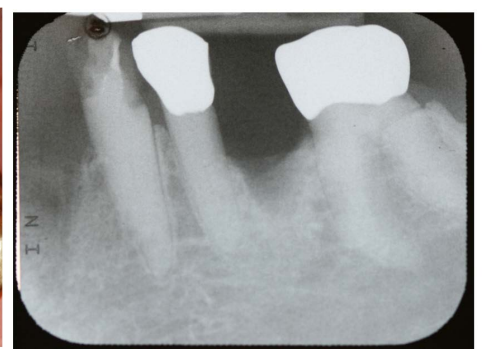

(b)

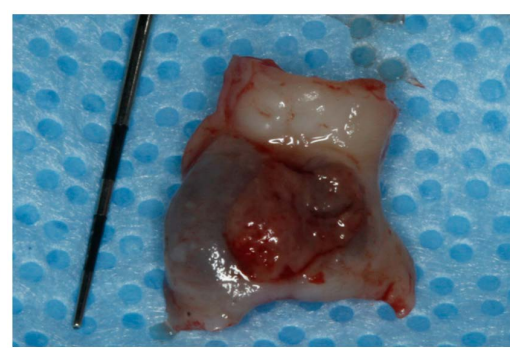

(c)

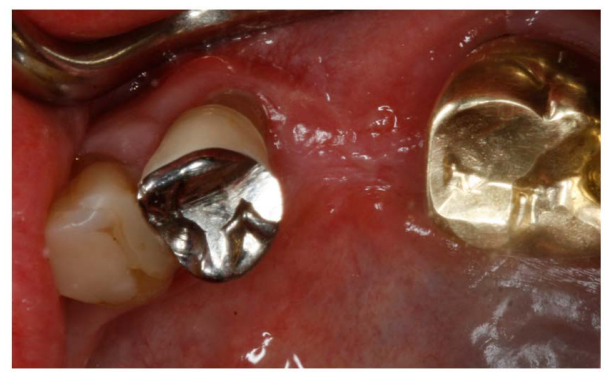

(e)

Figure 2. Recurring lesion 2 weeks after the initial excisional biopsy. (a) Intraoral view showing that the lesion recurred at the same location as the previous lesion; (b) Periapical radiograph showing no bone alterations; (c) Specimen removed by excisional biopsy (about $8 \times 10 \mathrm{~mm}$ ); (d) Clinical image at the 1-month evaluation; (e) Clinical image at the 2-month evaluation. 
demonstrate reduction in the concentration of PTH and Ca following the excisional biopsies. These blood test results would assist in establishing causality of the hyperparathyroidism and the PGCG.

This case report suggests that the hyperparathyroidism may have contributed to the development of the peripheral giant cell granuloma. However, we cannot exclude the potential role of local irritating factors.

\section{References}

[1] Neville, B.W. (2002) Soft Tissue Tumors. In: Neville, B.W., Damm, D. and Bouquot, J.W., Eds., Oral and Maxillofacial Pathology, Elsevier Sunders, Philadelphia, 437-479.

[2] Katsikeris, N., Kakarantza-Angelopoulou, E. and Angelopoulos, A.P. (1988) Peripheral Giant Cell Granuloma. Clinicopathologic Study of 224 New Cases and Review of 956 Reported Cases. International Journal of Oral and Maxillofacial Surgery, 17, 94-99. http://dx.doi.org/10.1016/S0901-5027(88)80158-9

[3] Kfir, Y., Buchner, A. and Hansen, L.S. (1980) Reactive Lesions of the Gingiva. A Clinicopathological Study of 741 Cases. Journal of Periodontology, 51, 655-661. http://dx.doi.org/10.1902/jop.1980.51.11.655

[4] Shadman, N., Ebrahimi, S.F., Jafari, S. and Eslami, M. (2009) Peripheral Giant Cell Granuloma: A Review of 123 Cases. Dental Research Journal (Isfahan), 6, 47-50.

[5] Giansanti, J.S. and Waldron, C.A. (1969) Peripheral Giant Cell Granuloma: Review of 720 Cases. Journal of Oral and Maxillofacial Surgery, 27, 787-791.

[6] Ozden, F.O., de Moraes, P.C., Sperandio, M., Soares, A.B., Araújo, V.C., et al. (2009) Peripheral Giant Cell Granuloma Associated with Dental Implants: A Rare Case Report. International Journal of Oral \& Maxillofacial Implants, 24, 1153-1156.

[7] Etoz, O.A., Demirbas, A.E., Bulbul, M. and Akay, E. (2010) The Peripheral Giant Cell Granuloma in Edentulous Patients: Report of Three Unique Cases. European Journal of Dentistry, 4, 329-333.

[8] Bernier, J.L. and Cahn, L.R. (1954) The Peripheral Giant Cell Reparative Granuloma. Journal of the American Dental Association, 49, 141-148. http://dx.doi.org/10.14219/jada.archive.1954.0138

[9] Eversole, L.R. and Rovin, S. (1972) Reactive Lesions of the Gingiva. Journal of Oral Pathology \& Medicine, 1, 30-38. http://dx.doi.org/10.1111/j.1600-0714.1972.tb02120.x

[10] Jaffe, H.L. (1953) Giant-Cell Reparative Granuloma, Traumatic Bone Cyst, and Fibrous (Fibro-Oseous) Dysplasia of the Jawbones. Oral Surgery, Oral Medicine, Oral Pathology, 6, 159-175. http://dx.doi.org/10.1016/0030-4220(53)90151-0

[11] Buchner, A., Shnaiderman-Shapiro, A. and Vered, M. (2010) Relative Frequency of Localized Reactive Hyperplastic Lesions of the Gingiva: A Retrospective Study of 1675 Cases from Israel. Journal of Oral Pathology \& Medicine, 39, 631-638. http://dx.doi.org/10.1111/j.1600-0714.2010.00895.x

[12] Motamedi, M.H.K., Eshghyar, N., Jafari, S.M., Lassemi, E., Navi, F., et al. (2007) Peripheral and Central Giant Cell Granulomas of the Jaws: A Demographic Study. Oral Surgery, Oral Medicine, Oral Pathology, Oral Radiology, and Endodontology, 103, e39-e43. http://dx.doi.org/10.1016/j.tripleo.2006.12.022

[13] Andersen, L., Fejerskov, O. and Philipsen, H.P. (1973) Oral Giant Cell Granulomas. A Clinical and Histological Study of 129 New Cases. Acta Pathologica Microbiologica Scandinavica Section A Pathology, 81, 606-616. http://dx.doi.org/10.1111/j.1699-0463.1973.tb03551.x

[14] Smith, B.R., Fowler, C.B. and Svane, T.J. (1988) Primary Hyperparathyroidism Presenting as a "Peripheral” Giant Cell Granuloma. Journal of Oral and Maxillofacial Surgery, 46, 65-69. http://dx.doi.org/10.1016/0278-2391(88)90303-5

[15] Silverman Jr., S., Ware, W.H. and Gillooly Jr., C. (1968) Dental Aspects of Hyperparathyroidism. Oral Surgery, Oral Medicine, Oral Pathology, 26, 184-189. http://dx.doi.org/10.1016/0030-4220(68)90249-1

[16] Carlotti, A.E., Camitta, F.D. and Connor, T.B. (1969) Primary Hyperparathyroidism with Giant Cell Tumors of the Maxilla: Report of Case. Journal of Oral and Maxillofacial Surgery, 27, 722-727.

[17] Martinez-Gavidia, E.M., Bagán, J.V., Milián-Masanet, M.A., de Miguel, E.L. and Pérez-Vallés, A. (2000) Highly Aggressive Brown Tumour of the Maxilla as First Manifestation of Primary Hyperparathyroidism. International Journal of Oral and Maxillofacial Surgery, 29, 447-449. http://dx.doi.org/10.1016/S0901-5027(00)80079-X

[18] Burkes Jr., E.J. and White Jr., R.P. (1989) A Peripheral Giant-Cell Granuloma Manifestation of Primary Hyperparathyroidism: Report of Case. Journal of the American Dental Association, 118, 62-64. http://dx.doi.org/10.14219/jada.archive.1989.0005

[19] Carvalho, Y.R., Loyola. A.M., Gomez, R.S. and Araújo, V.C. (1995) Peripheral Giant Cell Granuloma. An Immunohistochemical and Ultrastructural Study. Oral Diseases, 1, 20-25.

http://dx.doi.org/10.1111/j.1601-0825.1995.tb00152.x 
[20] Choi, C., Terzian, E., Schneider, R. and Trochesset, D.A. (2008) Peripheral Giant Cell Granuloma Associated with Hyperparathyroidism Secondary to End-Stage Renal Disease: A Case Report. Journal of Oral and Maxillofacial Surgery, 66, 1063-1066. http://dx.doi.org/10.1016/j.joms.2007.11.030

[21] Fraser, W.D. (2009) Hyperparathyroidism. The Lancet, 374, 145-158. http://dx.doi.org/10.1016/S0140-6736(09)60507-9

[22] Neer, R.M., Arnaud, C.D., Zanchetta, J.R., Prince, R. and Gaich, G.A. et al. (2001) Effect of Parathyroid Hormone (1-34) on Fractures and Bone Mineral Density in Postmenopausal Women with Osteoporosis. The New England Journal of Medicine, 344, 1434-1441. http://dx.doi.org/10.1056/NEJM200105103441904

[23] Dempster, D.W., Cosman, F., Kurland, E.S., Kurland, H., Nieves, J., et al. (2001) Effects of Daily Treatment with Parathyroid Hormone on Bone Microarchitecture and Turnover in Patients with Osteoporosis: A Paired Biopsy Study. Journal of Bone and Mineral Research, 16, 1846-1853. http://dx.doi.org/10.1359/jbmr.2001.16.10.1846

[24] Lundgren, E., Rastad, V., Thurfjell, E., Åkerström, G. and Ljunghall, S. (1997) Population-Based Screening for Primary Hyperparathyroidism with Serum Calcium and Parathyroid Hormone Values in Menopausal Women. Surgery, 121, 287-294. http://dx.doi.org/10.1016/S0039-6060(97)90357-3

[25] Mosekilde, L. (2008) Primary Hyperparathyroidism and the Skeleton. Clinical Endocrinology (Oxford), 69, 1-19. http://dx.doi.org/10.1111/j.1365-2265.2007.03162.x

[26] Parbatani, R., Tinsley, G.F. and Danford, M.H. (1998) Primary Hyperparathyroidism Presenting as a Giant-Cell Epulis. Oral Surgery, Oral Medicine, Oral Pathology, Oral Radiology, and Endodontology, 85, 282-284. http://dx.doi.org/10.1016/S1079-2104(98)90009-9

[27] Miller, P.D., Schwartz, E.N., Chen, P., Misurski, D.A. and Krege, J.H. (2007) Teriparatide in Postmenopausal Women with Osteoporosis and Mild or Moderate Renal Impairment. Osteoporosis International, 18, 59-68. http://dx.doi.org/10.1007/s00198-006-0189-8 